\title{
"É como festa dos Gojánéhj, só que é diferente": as danças na igreja dos Ikólóéhj Gavião de Rondônia
}

\section{"It's like the feast of Gojánéhj, but it's different": the dance in the church of the Ikólóéhj Gavião de Rondônia}

\author{
Lediane Fani Felzke \\ Instituto Federal de Rondônia - IFRO \\ e-mail: ledianeff@yahoo.com.br
}

\begin{abstract}
Resumo
O povo Ikólóéhj Gavião, grupo tupi residente na região central do estado de Rondônia, passou a conviver com agentes da Missão Novas Tribos do Brasil desde 1965. Nos primeiros quarenta anos de atividade missionária, as cerimônias religiosas eram estruturadas de acordo com o costume dos brancos e a adesão à igreja limitava-se a poucas famílias. Rituais de pajelança e festas ancestrais com a bebida fermentada continuavam existindo. Em 2006, aproximadamente, os indígenas decidiram levar as danças para o templo durante os cultos festivos, como os de Natal. Tal decisão provocou uma inflexão na relação com a missão. A adesão à igreja passou a ser majoritária e as festas ancestrais com bebida fermentada foram abandonadas momentaneamente. Nosso objetivo neste artigo é compreender os múltiplos significados das festas da igreja para os Ikólóéhj Gavião levando-se em conta que em alguns sentidos elas são como as festas xamânicas e em outro, são diferentes.
\end{abstract}

Palavras-chave: povo ikólóéhj gavião, igreja evangélica gavião, festas.

\begin{abstract}
The Ikólóéhj Gavião people, a Tupi group resident in the central region of the state of Rondônia, started to live with agents of the New Tribes of Brazil Mission, since 1965. During the first forty years of missionary activity, religious ceremonies were structured according to the custom of white people and church membership was limited to a few families. Pajelan rituals and ancestral feasts with the fermented drink continued to exist. In 2006, approximately, the natives decided to take the dances to the temple during festive services, such as Christmas. This decision caused an inflexion in the relation with the mission. Membership in the church became the majority and the ancestral feasts with fermented beverages were abandoned for a while. Our purpose in this article is to understand the multiple meanings of the church feasts for the Ikólóéhj Gavião taking into account that in some ways they are like shamanic festivals and in another they are different.
\end{abstract}

Keywords: people ikólóéhj gavião, protestant church gavião, feasts. 


\section{Introduzindo o tema}

Nos primórdios do século XX, o etnólogo alemão Koch-Grünberg percorreu parte das terras baixas sul-americanas no Brasil, na Venezuela e na Colômbia estudando os seus "nativos". É dele uma das primeiras menções a um culto compósito de elementos cristãos e xamânicos que grassava entre os Pemon da Venezuela, denominado Aleluia (BUTT COLSON, 1971, 1985). Constituído basicamente de canções e danças que se estendiam até o amanhecer, tal culto foi interpretado pelo autor como uma expressão ritualística menor e de pouco interesse para a Antropologia da época. KochGrünberg referiu-se ao rito como "baile atípico", "baile estranho" e à religião como "triste caricatura", "religião estranha", "religião louca".

Diferente da Antropologia do tempo de Koch-Grünberg, que se preocupava pouco com a presença missionária nas socialidades ameríndias, há alguns anos, os estudos etnológicos das Terras Baixas têm se debruçado sobre as interposições das missões e doutrinas cristãs (católicas e protestantes) na vida dos indígenas. É sobre alguns aspectos de tal interposição que trata este artigo, em especial sobre as danças que acontecem nos cultos da Igreja Evangélica Gavião. É assim que os Ikólóéhj Gavião, povo tupi de Rondônia chamam sua igreja, constituída a partir do trabalho de missionários da New Tribes Mission (NTM)/Missão Novas Tribos do Brasil (MNTB) que atuam entre eles desde 1965.

As impressões de Koch-Grünberg sobre aquele ritual de compleição cristã, emitidas há cerca de cem anos, chamaram minha atenção porque tive palpite semelhante na minha primeira experiência em uma festa da igreja ${ }^{1}$ entre os Ikólóéhj Gavião no ano de 2012. Cerca de oito anos antes, eu havia iniciado minha convivência com este povo em meio uma festa tradicional na aldeia. Naquele primeiro encontro, tomada da euforia típica dos neófitos, fascinou-me tudo que presenciei: as flautas, as músicas, as danças, a macaloba ${ }^{2}$ fermentada (i sòhn), a estética corporal e a ambientação. O auge daquela visita foi ter assistido a um primeiro - e não sabia eu à época, um último - ritual público de pajelança.

Ao me deparar com as festas da igreja, ainda embalada pela memória das festas tradicionais que havia acompanhado anteriormente, fui inicialmente

\footnotetext{
${ }^{1}$ No decorrer deste trabalho falarei em festa tradicional quando estiver tratando das festas ancestrais e festas da igreja para identificar as comemorações que ocorrem no âmbito da igreja, por ser esta forma utilizada pelos meus interlocutores para distinguir, na língua portuguesa, ambas as festas. Na língua gavião não há distinção, toda e qualquer festa é chamada ibalàe e equivale a dança. Festa e dança são indissociáveis.

${ }^{2}$ Bebida comumente elaborada com milho (ma'eg), mandioca (xibója) ou cará (mojá), equivalente à chicha, ao caxiri ou ao cauim. Doce nos primeiros três dias após a confecção, torna-se alcoólica depois do terceiro dia, a partir do que está apropriada para ser consumida nas festas.
} 
tomada por sentimentos semelhantes aos do etnólogo alemão. De certa forma, tais rituais pareceram a mim algo como um "baile atípico". No entanto, diferentemente dele, não havia como considerar tais eventos como "tema de pouco interesse à etnologia" (ABREU, 1995: 57), tendo em vista sua capacidade mobilizadora e seu alcance não apenas entre os Ikólóéhj, mas entre os Arara, moradores da mesma terra indígena, os Zoró e Suruí, habitantes de terras indígenas vizinhas e os Wari' que se deslocaram cerca de 700 quilômetros a partir da fronteira com a Bolívia para participar do Natal de 2013 na aldeia central dos Ikólóéhj.

A dança (ibalàe), que atraiu minha atenção na primeira vez que estive na aldeia, executada no terreiro sob o comando das flautas, continua fortemente presente na vida dos Ikólóéhj, mas agora no contexto da Igreja Evangélica Gavião e sob o comando de violão e teclado. Minha proposta, neste texto, é justamente compreender o estatuto destas festas na sociocosmologia ikólóéhj.

A este respeito, ouvi diferentes versões. Há as razões imputadas pelos missionários e por alguns indígenas crentes $^{3}$ - ou seja, as razões "dos brancos" - que operam numa perspectiva de ruptura com a sociocosmologia indígena, e há as motivações explicitadas por crentes e não crentes - as razões "dos índios" - que operam em continuidade com esta mesma sociocosmologia e que passam pela ampliação da socialidade 4 e pela festa como mediação entre a existência mundana e a espiritual, como já nos havia informado Hugh-Jones (1996) em seu trabalho sobre os movimentos milenaristas do noroeste amazônico.

As festas da igreja organizadas pelos Ikólóéhj podem ser compreendidas na mesma chave analítica utilizada por Sáez e Arisi (2013) ao atentarem para as transformações dos rituais ameríndios sob a influência dos brancos processos de imitação/invenção - como uma experimentação cujo propósito é o de efetivar alianças com diferentes outros, outras etnias, brancos de perto e de longe, animais, espíritos, antepassados e mortos.

Sugerimos aquí la posibilidad de entender los rituales como acciones 'de laboratorio'. Es decir, como ocasiones de establecer relaciones nuevas - modos nuevos de relación si se quiere - que serán eventualmente aprovechados en la vida

\footnotetext{
${ }^{3}$ Utilizo a categoria crente no sentido que lhe designam meus interlocutores, os seja, são os membros atuantes da igreja, aqueles que não estão afastados.

${ }^{4}$ Tomo esta categoria como entendida por Strathern (2014: 236), para referir "relações no interior das quais as pessoas existem" sem o hermetismo que passou a constituir o conceito "sociedade".
} 
cotidiana o pasarán a formar parte de la política y la economía corriente [...](SÁEZ e ARISI, 2013: 219).

É a partir da centralidade da festa para a construção e ampliação da socialidade entre si e com os outros, mas também como uma forma de antecipação momentânea da imortalidade póstuma, que procuramos compreender os múltiplos sentidos das festas/danças da igreja para os Ikólóéhj.

\section{Natal na aldeia: a festa animada de 2013}

Desde a chegada dos missionários protestantes, o nascimento de Cristo é celebrado entre os Ikólóéhj. Como aspecto constitutivo das estratégias evangelísticas, missionários de distintas ordens e agências, agregavam - e ainda o fazem -, ou progressiva ou abruptamente ${ }^{5}$, estes novos rituais entre os indígenas, na tentativa de conformar sua prática cristã.

Na festa de Natal de 2013, a igreja, situada ao centro da principal aldeia ikólóéhj, estava lotada, não apenas dos moradores locais, mas também dos visitantes citados acima, que vieram participar desta celebração natalina junto aos parentes ${ }^{6}$. Cerca de duzentas e cinquenta pessoas que estavam presentes naquele templo sem paredes laterais - junto de centenas de outras, acomodadas em redes penduradas nos tapiris ao redor da igreja -, aguardavam o início da celebração.

No palco, alguns rapazes organizavam seus instrumentos musicais: teclado, violão, guitarra e duas grandes caixas de som (sobre uma das quais fora instalado um pequeno globo giratório de luzes coloridas). Estes instrumentos animariam a festa durante os próximos dias. Desde o início da atuação missionária, um expressivo acervo de músicas cristãs com composições próprias em língua gavião foi formado e é sob o som de canções em língua materna que os Ikólóéhj dançam.

A abertura do evento ocorreu com orações e discursos de boas-vindas que não diferiam muito das celebrações das igrejas "dos brancos". Mas eis que os jovens no palco deram os primeiros acordes e os vocalistas passaram a cantar os hinos na língua gavião. Quando um primeiro quarteto de homens se levantou e, de braços dados, iniciou a dança, foram seguidos, timidamente a princípio, efusivamente na sequência, por grande parte das

\footnotetext{
${ }^{5}$ Como foi o caso dos Koripako do Alto Içana evangelizados por Sophie Muller, missionária da New Tribes Mission nos anos 1940, que, sob orientação da missionária, substituíram todos seus rituais pelas "Conferências Missionárias" realizadas no Alto Içana até hoje (XAVIER, 2013).

${ }^{6}$ Utilizado aqui e em outros momentos no sentido ampliado que lhe emprestou o Movimento Indígena para englobar as diversas socialidades indígenas em oposição aos "brancos".
} 
pessoas que até então permaneciam sentadas. Neste momento o ambiente se transformou: o foco central passou a ser o aglomerado de dançarinos em frente ao palco. O bailado, o globo de luzes coloridas, o mar de penas balançando, os chocalhos, os tiros de foguete, os gritos de "uhaa" e a coreografia circular, alternando o sentido horário e anti-horário, indicavam que se tratava de uma festa compósita de elementos dos brancos e dos indígenas, um "laboratório" de fato, na concepção de Saéz \& Arisi (2013). A presença de visitantes, afins potenciais, e a igreja lotada constituíam motivações a mais para a empolgação que tomou conta do lugar.

Mas nem sempre foi assim. Nos quarenta anos de atividade missionária anteriores à introdução da dança na igreja, as canções eram entoadas com o público sentado nos bancos, ao modo dos brancos. Este formato parecia não satisfazer os Ikólóéhj, pois dissociava a música da dança, algo impensável do ponto de vista indígena (SEEGER, 1980). A inserção das danças nos cultos festivos recompôs a utilização da música nos termos ikólóéhj e promoveu uma adesão majoritária à igreja. Vejamos como isso aconteceu.

A Igreja Evangélica Gavião segue os preceitos da NTM/MNTB. A teologia desta agência missionária se enquadra em uma vertente conhecida na literatura especializada como evangelical ou fundamentalista. Para situar esta vertente do protestantismo tomo aqui as palavras de Capiberibe (2007: 172) que a sintetizou nos seguintes termos:

[...] linha de pensamento religioso que se assenta na leitura literal da Bíblia, como continente da história da humanidade, confrontando-se diretamente com $o$ pensamento evolucionista vigente no campo das Ciências desde Darwin [...]. Esta corrente fundamentalista opõe-se radicalmente à linha de pensamento religioso mais progressista, formada principalmente por membros da elite eclesiástica que possuem cleros formados em seminários e vínculos com universidades, pregando teologias 'iberais' e ponto de propor o ecumenismo e uma leitura alegórica das escrituras em consonância com os descobrimentos da Ciência [...]. A oposição dos fundamentalistas em relação às outras correntes religiosas é tão radical a ponto de se negarem a dialogar com estas [...].

O termo "fundamentalista", por sua vez, data dos anos 1910 e baseia-se na publicação nos Estados Unidos, de doze volumes intitulados "Os Fundamentos", cujo mote principal é notadamente a defesa de um 
protestantismo literalista contra as correntes "liberais" evangélicas (CLOUTIER, 1988).

Nos primeiros quarenta anos em que os missionários fundamentalistas viveram com os Ikólóéhj, as festas e as danças não eram vistas com bons olhos. O maniqueísmo da pregação protestante imediatamente rotulou estes eventos, assim como o xamanismo e inúmeras outras práticas indígenas, como manifestações demoníacas. Trazer a ibalàe para a igreja era, portanto, impensável. Durante aquele longo período, as comemorações de Natal se limitavam ao culto e a uma refeição partilhada entre todos da aldeia, onde cada família contribuía com um tipo alimento. A forma de expressar alegria ensinada pelos missionários, dissociada das danças, diferenciava-se sensivelmente do que os Ikólóéhj entendiam por alegria sentimento intimamente relacionado à dança e ao consumo de ì sòhn, a macaloba azeda. Além disso, a proibição da dança feria profundamente a noção de imortalidade dos Ikólóéhj, cuja vida póstuma consiste na alegria plena, proporcionada pela dança que "não acaba nunca".

Por ser um culto eminentemente "de branco", os Ikólóéhj relutaram em aderir a ele amplamente. A "ouverture à l'autre" (LÉVI-STRAUSS, 1993), derivada diretamente do desequilíbrio perpétuo do dualismo das socialidades ameríndias - que prevê o ingresso de um terceiro termo na sociocosmologia (VIVEIROS DE CASTRO, 2000: 20) e que, aqui, é constituído pelos ensinamentos dos missionários -, tem os seus limites. Ou seja: ela não dispensa os termos já existentes e, sendo assim, enquanto as desejáveis coisas do mundo dos brancos estavam se inserindo rapidamente na aldeia Igarapé Lourdes7, os Ikólóéhj mantinham o controle desta "abertura ao outro", insistindo nas relações com as gentes ${ }^{8}$ dos outros planos cósmicos através da atuação dos seus xamãs, os vạváhéj, e fazendo festas com o uso abundante do ì sòhn. Concomitantemente, sentavam na igreja em dias de culto para cantar. Como iriam abdicar das festas, sendo estas o espaçotempo de realização da socialidade ampliada entre humanos e não humanos, da emergência da identidade ikólóéhj e da antecipação da festa/dança ininterrupta do mundo póstumo? Naquele momento não o fizeram.

Foram nos últimos dez anos que os crentes da Igreja Evangélica Gavião encontraram um meio de expressar sua alegria de um modo indígena em um contexto pautado pela moralidade rígida ensinada pelos missionários.

\footnotetext{
${ }^{7}$ Aldeia fundada no transcorrer do contato interétnico e que centralizou pela primeira vez as malocas dispersas no território em um único lugar devido a presença da FUNAI, do atendimento de saúde e da missão.

${ }^{8}$ Aprendi com meus interlocutores a identificar os entes não-humanos como "gente" e não como "espírito".
} 
Foram os próprios crentes que insistiram com o tema da dança na igreja. "Somos um povo festeiro", explicou Máádjóhr, um dos antigos líderes da igreja e um dos principais defensores das danças nos cultos. "A gente estudou muito a bíblia e viu que podíamos adorar a Deus do nosso jeito, dançando. Lá no salmo 150 fala isso, 'louve o senhor com flautas, com danças'. A gente estudou muito e viu que não tinha problema", afirmou meu interlocutor. Depois desta fase de estudos, a decisão de dançar nos cultos foi tomada.

Esta decisão, desta vez apoiada pelos missionários ${ }^{9}$, provocou dois movimentos: de um lado, depois de quarenta anos de condenação das danças, a decisão dos indígenas de festejar dançando as datas emblemáticas cristãs, como o Natal, repercutiu no crescimento exponencial dos frequentadores da igreja, ao menos nas épocas próximas aos festejos. De outro lado, a música, quando reencontrou a dança (SEEGER, 1980) devolveu aos indígenas a capacidade de se mobilizar em torno das atividades cristãs como já se mobilizavam antes, em torno das festas tradicionais. Estas, desde então, não foram mais praticadas.

Dançar é "costume do índio", assim como beber macaloba azeda (ì sòhn). A primeira foi incorporada ao ritual cristão. Assim, a igreja deixou de ser apenas coisa "de branco" e passou a ser coisa de índio, fato que constitui ao mesmo tempo uma transformação e uma domesticação (HOWARD, 2002). Já o i sòhn foi banido. Este era o veículo para se atingir o estágio de plena alegria nas festas tradicionais, como observou Lima (2005: 234) entre os Yudjá: "[o] tempo de embriaguez não é para contar histórias ou fazer discurso, mas para se cantar e dançar em grupo, que são as formas por excelência da expressão de alegria".

Alguns crentes argumentam que além da alegria, ele trazia o "beber até cair", o "brigar" e o "bagunçar", atitudes condenáveis pelos ensinamentos cristãos. Seu banimento nos leva a outra questão: o que ficou em seu lugar como veículo de alegria? Ao que parece, a aglomeração nunca vista anteriormente - cerca de mil pessoas de várias etnias envolvidas -, aliada aos instrumentos musicais dos brancos e suas potentes caixas de som, provocam uma efervescência singular, por si só alterante, que tornou o $i$ sòhn dispensável. Experimentar de forma tão intensa em vida o que estava destinado apenas ao mundo póstumo - ou seja, música, dança e alegria permanente - parece satisfazer o desejo dos Ikólóéhj de se afastar da vida ordinária através das festas da igreja. No entanto, há distinções entre as

${ }^{9} \mathrm{O}$ casal de missionários que trabalhou mais de 40 anos com os Ikólóéhj se aposentou e retornou para a Alemanha, de onde eram originários. Foram substituídos por missionários brasileiros que entendem a dança como um "aspecto da cultura" dos indígenas. 
motivações dos indígenas para dançar e as motivações ensinadas pelos missionários. Vejamos.

\section{É preciso ser crente "para não dançar à toa"}

Segundo as normas da igreja, ser crente é requisito necessário para participar da dança - "para não dançar à toa [...] para saber que está dançando pra Jezój [...], que não é brincadeira", como explicou um dos líderes crentes em uma reunião de preparativos do Natal. Diante dessa exigência houve uma adesão em massa à igreja depois da última festa tradicional, em 2007. Ainda hoje, com a proximidade das festas de fim de ano, dezenas de pessoas, especialmente jovens, decidiram se converter ou retornar à igreja pedindo perdão por algum pecado cometido. Esta decisão é expressa primeiro em uma reunião da diretoria - como é chamado o grupo de líderes da igreja - e, na sequência, nos cultos públicos.

A festa dos "cinquenta anos de evangelização", ocorrida em fevereiro de 2015, constituiu um apelo irresistível para que muitos "afastados" retornassem à igreja. $O$ desejo de ser autorizado a dançar em uma festa tão concorrida fez com que muitos não quisessem permanecer apenas como espectadores. Por conta disso, nos cultos que a antecederam, sobreveio uma abundância de "conversões" (amapê) e "retornos" (abirixàe) de jovens e adultos. Estes cultos ocorreram com a igreja lotada, tanto de fieis contumazes quanto de famílias que eu ainda não havia encontrado neste ambiente desde que chegara à aldeia, doze meses antes. $O$ volume de conversões e retornos suscitou comentários variados. "Viu só quantos jovens voltando pra igreja?", observou alguém. Outros são mais desconfiados: "isso daí é só porque tem a festa chegando, é da boca pra fora". Nos cultos seguintes outras dezenas tomaram o mesmo caminho.

Os casos de crentes que constantemente "pecam", se afastam, se arrependem, retornam, voltam a "pecar" e se arrependem novamente e assim sucessivamente são bastante comentados: "fulano está voltando pela décima vez, ninguém mais acredita". Era corrente nas conversas que tantas conversões e retornos eram motivados unicamente pela festa. "Ninguém quer ficar de fora" foi o argumento mais utilizado neste caso, mas tal atitude sofre severas críticas dos mais velhos, como um amigo ikólóéhj me explicou:

[...] muitos desses jovens que vão à frente 'se entregar pra Jesus' não sabem direito o que estão fazendo. É uma brincadeira. Orestes me ensinou, quando eu era jovem e queria aceitar Jesus, ser crente, que eu já era de Deus, mas que essa decisão 
exigia maturidade e, por isso, eu devia pensar melhor. [...] Esse pessoal fica brincando com Deus, não levam a sério não.

Ao perguntar sobre quais atitudes são passíveis de afastar uma pessoa da igreja e que demandam uma demonstração pública de arrependimento para que a mesma pessoa possa retornar, meus interlocutores responderam que somente aqueles que cometem erros graves do tipo "beber", "bagunçar", "andar com mulher", "namorar escondido", são afastados e devem pedir perdão para poder retornar à igreja. Tais movimentos são frequentes, pois é muito difícil seguir a rígida moralidade imposta pelo fundamentalismo cristão.

Nas noites de festa, enquanto as pregações eram proferidas à frente, ao fundo da igreja posicionavam-se as moças e os rapazes solteiros adornados com pintura de jenipapo. As meninas exibiam ainda maquiagem comprada na cidade. Claramente não estavam atentos aos discursos. Ao tempo em que os pregadores brancos e indígenas se preocupavam em falar da salvação, a preocupação destes jovens era de outra ordem. O cruzamento de tímidos olhares, os cochichos e as risadinhas sutis, denunciavam que a proibição de dançarem juntos não impediu que este momento fosse empregado para atrair a atenção de um parceiro, dentre os cônjuges preferenciais. Pelo menos entre os solteiros, esta empreitada é uma das razões de ser (senão a principal) das festas.

Entre os adultos, o momento mais esperado era o da dança. Os dirigentes do culto parecem ter compreendido isso muito bem, porque logo após as leituras bíblicas e as rápidas falas, os músicos voltaram a tocar e o balé de plumas ocupou novamente o centro do templo.

O tempo chuvoso em toda região (afinal nos encontrávamos em pleno inverno amazônico) não desanimou os participantes. A precariedade das estradas fez com que enormes esforços fossem dispendidos por muitos para poderem se fazer presentes. Não estar presente era impensável até para os indígenas que não frequentam a igreja. Muitos destes ficaram apenas observando; outros ignoraram as proibições e se puseram a dançar.

Considerado desde os tempos ancestrais como período de respeito, a estação chuvosa é a época dos Gojánéhj - gente das mais importantes da mitologia ikólóóéh. Tratam-se dos donos das águas, liderados por Goján Maloloa, seu chefe. O mundo aquático, subaquático, bem como as águas "de cima", o arco-íris, os trovões, os raios e os relâmpagos, são associados a eles e a sua divisão celeste, o Goján Gíhr. Na esfera terrestre, Goján é o criador e o doador do milho aos humanos. A fartura das colheitas está relacionada a ele. 
Demiurgo respeitado e temido, era no período chuvoso - em que "não se deve brincar", como explicam meus interlocutores - que ocorria a festa dedicada aos Gojánéhj e ao seu chefe Goján: a festa do milho verde. Estabelecer relações amistosas com ele era a garantia de abundância de milho, de um período chuvoso curto e, portanto, do afastamento da possibilidade do dilúvio derradeiro que virá acabar com o mundo terreno. A temporalidade da festa de Natal coincide com a temporalidade da sua festa. Como disse um interlocutor em um dia de preparação do Natal: "é como festa de Gojánéhj, só que é diferente". Tal afirmação, aparentemente ambígua, nos diz muito sobre os sentidos da festa da igreja, ou seja, "é como" em um nível de análise e "é diferente" em outro.

Durante a festa da igreja, vários discursos de pregadores indígenas enfatizaram o quanto os crentes não temem mais os Gojánéhj transformados em demônios pelo ensino protestante fundamentalista -, e que Jesus é quem protege aqueles que o seguem. A despeito destas preleções no contexto público da igreja, conversas privadas e ações quotidianas revelam que associados à desejada proteção de Jesus (reputado por alguns como a mais poderosa das gentes que se relacionam com os Ikólóéhj), o respeito e as interdições em relação aos Gojánéhj operam sistematicamente na vida ordinária.

Ao mesmo tempo em que a ruptura com a "cultura antiga" foi anunciada como um passo necessário para a conversão, os pregadores indígenas insistiram que esta conversão e a igreja "não impedem a cultura". Seria um contrassenso? Penso que não, pois os pregadores reproduziram o discurso missionário de que há "elementos bons e maus" na "cultura antiga". Para eles os "bons elementos" devem ser "preservados". Basicamente a língua, a dança e a cultura material são evocadas pelos oradores indígenas e missionários como argumento contra aqueles que acusam a missão de descaracterizar a cultura indígena.

Elementos como o xamanismo, as festas tradicionais com consumo do $i$ sòhn e a relação com os entes da cosmologia, por sua vez, são considerados maléficos, associados à ação de Satanás e, portanto, devem ser eliminados do universo Ikólóéhj. Durante tais discursos a plateia ouvia atentamente e em silêncio, como pede a etiqueta ikólóéhj. Não obstante, após a festa, algumas visitas que realizei nas casas mostraram que esta doutrina maniqueísta ensinada pelos missionários e replicada pelos pregadores indígenas - "lado bom e lado mau" - não reverbera da mesma forma entre os ouvintes. Seu entendimento a respeito é muito mais complexo. 
Entre aqueles que não frequentam a igreja há uma unânime defesa das festas tradicionais, dos vạváhéj e do xamanismo. Entre os frequentadores há dois posicionamentos. As pessoas mais envolvidas, que fazem parte da liderança da igreja, que auxiliam os missionários, que acompanham mais de perto suas atividades e ensinam a palavra de Deus durante os cultos; geralmente desqualificam a "cultura dos antigos" e utilizam um discurso de ruptura - mesmo porque se não o fizessem, estariam contrariando um dos estatutos primordiais do protestantismo fundamentalista. Tal estatuto foi observado por Caco Xavier ao pesquisar a conversão dos Koripako do Alto Içana, evangelizados por Sophie Muller nos primórdios da atuação da NTM no Brasil, em fins dos anos 1940.

Por analogia, o cristão é também chamado a uma drástica ruptura, devendo renunciar e a deixar para trás ele mesmo (sua 'velha natureza', a 'carne'), este mundo (o 'cosmos') e esta vida, em direção a uma 'nova criatura', a um novo mundo (seja o paraíso futuro, seja o corpo da Igreja de Cristo), e a uma nova vida junto a Deus (Romanos 6) (XAVIER, 2013: 209).

A despeito de esta ser, de fato, a meta da evangelização protestante, não se percebe esta "drástica ruptura" entre os Ikólóéhj. Não que os indígenas sejam incapazes de compreender conceitos abstratos tais como "velha natureza", "corpo da Igreja de Cristo", mas para eles o mundo espiritual sempre fez e, ao que parece, continua fazendo parte da natureza e das experiências. Neste sentido é que se posiciona o outro grupo que frequenta a igreja. Aqueles que conheceram, conviveram com os xamãs e participaram das festas e dos rituais de pajelança, não concordam com estes discursos, embora não expressem isso publicamente - o que é compreensível e até esperado, pois como poderiam se posicionar contrariamente aos parentes? Em público não o fazem. No âmbito privado, no entanto, vários são os posicionamentos divergentes.

Durante uma visita, ao perguntar para meu interlocutor sobre os discursos proferidos na igreja, que desqualificaram os xamãs, considerando-os "servos de Satanás", e compararam os rituais como coisas do Diabo; ele lembrou que os pregadores ainda são inexperientes: "estes jovens não sabem o que estão dizendo, eles não conheceram os vạváhéj e não viram como eles trabalhavam".

Portanto, mesmo entre os crentes não há unanimidade sobre o quanto devem se afastar da "cultura dos antigos" para seguir esta nouvelle religion dos brancos, como denominou Sophie Cloutier (1988) ao analisar a conversão dos Zoró nos anos 1980, que ocorreu sob influência direta dos 
crentes Ikólóéhj. Ocorre para a maioria dos crentes o mesmo que Vilaça (2008: 177) observou entre os Wari':

Sendo assim, a adoção do cristianismo como algo novo $e$ externo não contradiz a afirmação de continuidade entre essa religião e a cultura nativa, se tomarmos como ponto de partida a premissa básica do interesse deles e de outros povos ameríndios na captura da perspectiva do outro, seja ele animal, inimigo ou branco.

Apesar das insistentes pregações ao contrário e dos discursos de negação, os entes cosmológicos, os outros, os que foram vistos, ouvidos e/ou sentidos por eles próprios, pelos xamãs e pelos seus ancestrais, continuam sendo respeitados em alguma medida. Esta aparente contradição não parece preocupar meus interlocutores, que não veem problemas em manter sua perspectiva ao mesmo tempo em que "capturam" a perspectiva dos brancos - neste caso, o cristianismo protestante fundamentalista.

Nas conversas informais, nas horas seguintes à dança que encerrou após o amanhecer, depois de um breve sono, meus amigos contaram sobre suas motivações para virem até a festa, enfrentando chuva e atoleiros. "Ah, a gente veio brincar um pouco, né" explicou um jovem de outra aldeia da T.I. Igarapé Lourdes, que fez duas viagens com seu carro para deslocar toda sua família. "A gente veio encontrar os parentes", falou sorrindo um homem de uma aldeia distante. Já um morador local resumiu assim: "a gente participa da festa pra dançar e pra se alegrar com Deus".

Brincadeira, encontro e alegria são as palavras chave que abrangem as intencionalidades de muitos dos presentes, não apenas ikólóéhj, mas também de outras etnias. Outras expressões comuns que ouvi foram "conhecer outras pessoas, outros irmãos", "dar uma olhada no movimento" e "encontrar o pessoal".

Portanto, se de um lado - no nível dos discursos, na ausência de ì sòhn, no tipo de aparato musical, nos elementos dos brancos presentes - trata-se de uma festa diferente das ancestrais; no que diz respeito à socialidade (incluindo aí as relações sociais com humanos e não humanos), à antecipação da imortalidade, aos namoros, à busca de alegria, parece ser a mesma festa - transformada e atualizada, evidentemente - que está em andamento.

A preocupação dos pregadores, indígenas ou não, de que as festas da igreja sejam associadas às festas tradicionais fica clara na insistência com que relembram os ouvintes qual deve ser a motivação para dançar: "a gente 
dança para lembrar que Paadjaj $^{10}$ nos salvou do pecado". A necessidade de reafirmar com frequência, nas pregações, o sentido que a festa deve ter e a razão pela qual se deve dançar é sintomático que as lideranças da igreja são conscientes de que nem todos os participantes dançam pensando em Deus (Paadjaj) e Jesus (Jezój). Sugiro que o desejo de ampliar a socialidade e de antecipar a imortalidade através de momentos alegres sejam as principais motivações, independentemente de ser Jezój ou os Gojánéhj a se fazerem presentes no evento.

De qualquer forma, independente do estatuto que o Deus cristão assume, o mesmo respeito dispensado aos espíritos durante as festas tradicionais deve ser franqueado a ele durante as festas da igreja. Um dos dançarinos mais empolgados me afirmou que da mesma forma que Goiánéhj, "Jesus também fica brabo quando as crianças não respeitam". "Crianças" aqui é a categoria utilizada para se referir aos solteiros, independente da idade. "Respeito", por sua vez, reporta-se à etiqueta prescrita, que no caso de Jesus se refere especialmente ao não beber e ao não namorar.

Tal como as queixadas, o milho, a água, as tabocas de confeccionar flecha, a floresta, e outros entes, os Ikólóéhj já tinham um dono. Este dono, no entanto, não interferia diretamente na vida das pessoas como o Paadjaj cristão o faz. No protestantismo fundamentalista esta interferência se objetiva na forma de exigências morais (não namorar, não beber), distintas em vários sentidos, daquilo que os Ikólóéhj entendem como boa conduta (ética nas relações), o que torna difícil para os indígenas se submeterem a tais interferências.

Paadjaj, que sempre foi conhecido dos Ikólóéhj, era tão ausente que não há referências a ele na mitologia. Nenhuma festa se fazia para recebê-lo no meio dos homens como no caso do outro demiurgo (Goján) e das gentes do céu, os Garpiéhj. O Paadjajda Bíblia, por sua vez, é homenageado em eventos específicos, as festas da igreja. Neste sentido, é compreensível a insistência dos missionários e da diretoria para que apenas os crentes dançassem, para demarcar uma clivagem em relação a qualquer outra intencionalidade. Apesar de todas as exortações o fato é que, na efervescência do momento, algumas pessoas afastadas por beber e namorar dançaram. Também aqueles que não frequentam a igreja ordinariamente, aproveitaram o Natal e se alegraram junto aos demais.

\footnotetext{
${ }^{10}$ Paadjaj (lit. nosso dono), ente da mitologia ikólóéhj que habita a aldeia mais distante do céu e cujo nome não era pronunciado por respeito. A partir da pregação missionária, foi associado pelos Ikólóéhj ao criador mítico, Gorá. A partir de então seu nome passou a ser amplamente anunciado e utilizado nos textos escritos da missão.
} 
A festa de Natal de 2013 foi considerada pelos meus interlocutores como uma festa exitosa, muita gente, muita comida, muita música, muita dança e, especialmente muitos visitantes de longe. No ano seguinte (2014) a comemoração de Natal foi considerada desanimada, pois não contou com a presença de visitantes de outras etnias. A principal razão para a desmobilização em torno da festa da aldeia Ikólóéhj naquele é uma grande festa estava programada para uma das aldeias da Terra Indígena Zoró (MT), próxima a T.I. Igarapé Lourdes. Na aldeia Ikólóéhj permaneceram presentes apenas os moradores locais. A ausência dos visitantes tornou o Natal desanimado na perspectiva daqueles que permaneceram na aldeia. "Este ano tá tudo morto, ninguém se visitando", reclamaram. A animação retornou em fevereiro de 2015, na festa dos cinquenta anos de evangelização.

\section{Os cinquenta anos de evangelização: a festa animada de 2015}

Em 25 de janeiro de 1965, os primeiros missionários protestantes chegaram às aldeias dos Ikólóéhj. Dizem os crentes que este é "o dia que a palavra de Deus chegou até nós". Desde então, os Ikólóéhj passaram por diferentes fases de relacionamento com estes brancos. Estas fases se alternaram entre a conversão quase unânime (anos 1960), o abandono igualmente quase consentâneo (década de 1980) após a expulsão dos missionários (1979), a solicitação para seu retorno à aldeia (1992), a adesão massiva depois da implantação das festas na igreja (2007), a frequência alta nos dias que antecedem a festa, sua redução nos dias seguintes aos festejos, ou seja, relações dinâmicas operam desde o princípio do trabalho missionário. Os Ikólóéhj, portanto, não fogem à inconstância observada nos "anos iniciais de proselitismo missionário entre os Tupi" (VIVEIROS DE CASTRO, 2011: 188).

Embora padres salesianos já tivessem falado do Deus dos brancos antes dos missionários da NTM, estas primeiras tentativas foram ignoradas. Os missionários protestantes, por sua vez, tiveram uma atuação mais sistemática, duradoura e trouxeram coisas que interessavam aos Ikólóéhj, tais como os cuidados de saúde, os medicamentos que eram efetivos contra as epidemias, a palavra escrita, uma pregação voltada para a boa conduta na relação entre as pessoas e a promessa da imortalidade que os Ikólóéhj havia recusado nos tempos míticos. A aceitação interessada compõe o primeiro momento da presença missionária entre os ameríndios como deixam claro as etnografias de Capiberibe, $(2006,2007)$ sobre os Palikur de Roraima, de Wright $(1999,2004)$ sobre os Baniwa do Alto Rio Negro, de Vilaça (1999, 2007, 2008) sobre os Wari' de Rondônia; de Gallois \& Grupioni (1999) 
sobre os Wajãpi do Amapá, de Morgado (1999) sobre os Wayana e Aparai também do Amapá, entre outros.

O contato pacífico, não violento e atencioso dos missionários veio ao encontro dos interesses dos Ikólóéhj, pois, de toda forma, uma negociação se estabelece em torno daquilo que interessa aos índios ou, como diz Wright (1999: 14), "as transformações efetuadas nas culturas indígenas por missionários cristãos, durante o tempo, raramente tem sido o resultado de um processo simples de imposição". O retorno às danças, no contexto da igreja, é emblemática neste sentido.

No início da evangelização, o aprendizado do português pelos Ikólóéhj era um destes interesses. Aos missionários importava, por outro lado, dominar a língua Gavião para a posterior descrição e tradução da bíblia. A tradução da bíblia para a língua nativa, evidentemente, é o "ponto zero" de qualquer empresa missionária levada a cabo pelas agências protestantes entre povos indígenas, pois "só quando for possível expressar-se na língua nativa, será possível iniciar a evangelização e a tradução" (ALMEIDA, 2004: 42).

Nos primeiros tempos, sem compreender objetivamente o significado da presença dos missionários - embora estes, desde o primeiro encontro, tenham atribuído sua estada ao ensino sobre Deus - parece ter havido um pequeno desentendimento em função desta disjunção de interesses, como explicou um idoso: "o pessoal queria aprender português, aí o missionário falou, 'primeiro vocês me ensinam a língua de vocês, depois eu ensino português'". Foi o que aconteceu. Os Ikólóéhj, que até aquele momento, impactados pelo contato interétnico, se esforçavam para aprender 0 português e se comunicar nos códigos dos brancos, consideraram de grande valor aquelas pessoas que se dedicaram a aprender sua língua para transformá-la em "palavra escrita" - reputada pelos índios como sinônimo de verdade - e ainda os ensinaram a lê-la. Como afirma Vilaça (2016: 54):

Here we can understand the central importance for the missionaries of teaching the natives to read and write, which not only was intended to solve the problem of the correct transmission of the 'true' facts but also was related to a basic practical contingency: making the Bible available in the native idiom only makes sense if there are readers.

A presença da palavra escrita desde o início do trabalho missionário foi um elemento crucial para a evangelização. Várias pesquisas tratam sobre o poder que a escrita exerce sobre os ameríndios. Sua associação à verdade é sublinhada por Capiberibe (2007) entre os Palikur; por Queiroz (1999) e Dias Junior (2006) entre os Waiwai; por Vilaça (2016) entre os Wari'; e opera entre 
os Ikólóéhj. Em várias ocasiões ouvi conclusões do tipo "se está escrito é porque deve ser verdade".

Cinquenta anos após o início deste processo de tradução assisti, na noite de abertura da festa 'dos cinquenta anos", a mais um "experimento". Pela primeira vez os Ikólóéhj traduziram para a linguagem cristã, a música de um de seus instrumentos musicais mais emblemáticos, de seu uso exclusivo, as flautas tortoráv.

Elas foram tocadas no ambiente da igreja e acompanhadas por um grupo de homens vestidos de pinturas corporais, colares, palha e cocares. Mas desta vez o som das flautas não exaltava as histórias dos Ikólóéhj ou da natureza como descrevem Meyer e Moore (2013), os tons das notas musicais remetiam a Jesus Cristo.

O grupo ingressou ao templo com os três flautistas executando a canção, os demais acompanhando, com os gritos habituais e os chocalhos nos tornozelos marcando o ritmo. Foram recebidos com tímidos aplausos e curiosidade pela plateia. Por quase cinco minutos, enquanto dançavam, as flautas entoavam repetidamente: "Nós estamos gratos porque nosso Salvador nos salvou". A ideia, com esta apresentação, era mostrar para os presentes - para os brancos em especial - que não há incompatibilidade entre o cristianismo e a "cultura" dos ikólóéhj, sugiro, no entanto, que são os Ikólóéhj atualizando sua cultura através da religião dos brancos assim como o fizeram em outros momentos ao absorver elementos cosmológicos de outros grupos étnicos.

A natureza da aproximação dos missionários, muito distinta da aproximação de outros brancos, seringueiros, marreteiros, gateiros e garimpeiros, é sempre lembrada pelos Ikólóéhj e, salvo as devidas proporções, encontra certa similitude com a aproximação da missionária Sophie Muller no alto rio Negro em uma época de exploração dos Baniwa pelos "patrões da borracha", comerciantes e funcionários do SPI. Wright (1999: 179) observa que "[...] as estratégias que ela ofereceu para confrontar as corrupções e a violência do mundo dos brancos com certeza eram uma razão importante para seu sucesso nessa área".

Na festa dos "cinquenta anos", passado este momento de "abertura" com os discursos e as flautas tortoráv, os músicos começaram a tocar de cima do palco e os dançarinos ocuparam, animadamente, não apenas o centro da igreja, mas os arredores. Desta vez a dança se estendeu para o pátio ao lado e circundou a igreja. Sob um ritmo mais eletrizante do que eu já havia presenciado, os crentes suavam e riam muito. 


\section{À guisa de conclusão}

No dia de encerramento da "festa dos cinquenta anos", no pátio iluminado ao lado da igreja, cada etnia presente foi chamada a dançar separadamente. Zoró, Arara e Ikólóéhj se revezaram na coreografia. Uma pessoa que não costuma dançar justificou para mim: "eu fui porque fiquei com medo que ficassem poucos gavião, aí ia ficar chato".

E êxito da festa está associado à presença de muitos visitantes. A alegria só é plena se houver a possibilidade de se relacionar com afins. Tudo na festa se encaminha para tornar afins potenciais em afins reais. O período da festa é o "tempo dos Gojánéhj", época de realização da festa do milho verde, dedicada a Goján. Alguns elementos nos dizem que se trata, para os Ikólóéhj, da mesma festa: música/dança, alegria, temporalidade e afinização. Em outros sentidos, sugiro que eles entendem esta festa como uma ruptura com as festas tradicionais. O principal diacrítico, como já apontamos, é a ausência do ì sòhn e a mudança de lugar, se antes ocorria no terreiro da aldeia, agora acontece no ambiente da igreja. Outra distinção é o formato com que se dá a relação com os seres cosmológicos. Se nas festas tradicionais a presença das gentes dos outros planos em comunicação direta com os Ikólóéhj era o evento central, nas festas da igreja a comunicação com Deus e Jesus cristo ocorre nos momentos de oração enquanto que o evento central passou a ser a dança em si. Esta tornou-se a ação mais aguardada por todos.

Composta de continuidades e rupturas com as festas tradicionais, sugiro que as festas da igreja constituem uma forma atualizada daquelas, em constante transformação, um "laboratório" como indicaram Sáez e Arisi (2013) onde os Ikólóéhj encontraram uma forma de ampliar suas relações sociais com os outros, sejam eles de outras aldeias ou de outros planos cosmológicos; se aproximando do "ser branco" sem deixar de "ser índio". Neste processo de experimentação, novos elementos (dos brancos e dos índios) vão sendo incorporados. Neste sentido, hoje a igreja é um dos principais instrumentos para que os Ikólóéhj exerçam sua criatividade e encontrem formas de estar no mundo.

\section{Referências Bibliográficas}

ABREU, Stela Azevedo. Aleluia: o banco de luz. UNICAMP, 1995.

ALMEIDA, Ronaldo de. "Traduções do fundamentalismo evangélico". In: WRIGHT, Robin (org.). Transformando os deuses: Igrejas evangélicas, pentecostais e neopentecostais entre os povos indígenas no Brasil. Vol. 2. Campinas, SP: Ed. Unicamp, 2004. 
BUTT COLSON, Audrey. "Hallelujah among the Patamona Indians". Antropologica. N.28, 1971.

"Routes of knowledge: an aspect of regional integration in the circum-Roraima area of the Guiana Highlands". Antropologica. N.63-63, 1985. (p.103-149)

CAPIBERIBE, Artionka. "Sob o manto do cristianismo: o processo de conversões Palikur". In: In: MONTERO, Paula (org.). Deus na aldeia: missionários, índios e mediação cultural. São Paulo: Globo, 2006.

CAPIBERIBE, Artionka. Batismo de fogo: os Palikur e o cristianismo. São Paulo: Annablume, 2007.

CLOUTIER, Sophie. Une nouvelle éthique em rupture avec la tradition: la conversions des Indiens Zoró à l'évangelisme de la Mission Nouvelles Tribus. Département d'anthropologie. Faculté des arts et de sciences. Université de Montréal, 1988.

DIAS JUNIOR, Carlos Machado. Entrelinhas de uma rede: Entre linhas Waiwai, 2006. (Tese de doutorado).

GALLOIS, Dominique Tilkin; GRUPIONI, Luis D. "O índio na Missão Novas Tribos". In: WRIGHT, Robin (org.). Trasformando os deuses: os múltiplos sentidos da conversão entre os povos indígenas no Brasil. Campinas, SP: Ed. Unicamp, 1999.

HOWARD, Catherine. "A domesticação das mercadorias: estratégias Waiwai". In: ALBERT, Bruce; RAMOS, Alcida R. Pacificando o branco: cosmologias do contato no Norte-Amazônico. São Paulo: UNESP,: Imprensa Oficial do Estado, 2002.

HUGH-JONES, Stephen. "Shamans, prophets, priests and pastors". Shamanism, history, and the state. p. 32-75, 1996.

LÉVI-STRAUSS, Claude. História de lince. São Paulo: Companhia da Letras, 1993[1991].

LIMA, Tânia Stolze. Um peixe olhou pra mim: o povo Yudjá e a perspectiva. São Paulo: Editora UNESP: ISA; Rio de Janeiro: NuTi, 2005.

MEYER, Julien \& MOORE, Denny. "Arte verbal e música na língua Gavião de Rondônia: metodologia para estudar e documentar a fala tocada com instrumentos musicais". Boletim do Museu Paraense Emílio Goeldi. v. 8, n. 1. Jan-Abr. Belém, 2013. p.113-128. 
MORGADO, Paula. "O sentido das missões entre os Wayana e Aparai do Paru". In: WRIGHT, Robin (org.). Transformando os deuses: os múltiplos sentidos da conversão entre os povos indígenas no Brasil. Campinas, SP: Ed. Unicamp, 1999.

QUEIROZ, Ruben Caixeta de. "A saga de Ewká: epidemias e evangelização entre os Waiwai". In: WRIGHT, Robin (org.). Transformando os deuses: os múltiplos sentidos da conversão entre os povos indígenas no Brasil. Campinas, SP: Ed. Unicamp, 1999.

SÁEZ, Óscar Calavia; ARISI, Barbara. "La extraña visita: por una teoría de los rituales amazónicos"/The Strange Visitor: Towards a Theory on Amazonian Rituals. Revista Española de Antropología Americana. v. 43, n. 1, p. 205, 2013.

SEEGER, Anthony. Os Índios e nós: estudos sobre sociedades tribais brasileiras. Rio de Janeiro: Campus, 1980.

STRATHERN, Marilyn. "O conceito de sociedade está teoricamente obsoleto?" In: O efeito etnográfico. São Paulo: Cosac \& Naify, 2014.

VILAÇA, Aparecida. "Cristãos sem fé: alguns aspectos da conversão dos Wari (Pakaa Nova)". In: WRIGHT, Robin (org.). Transformando os deuses: os múltiplos sentidos da conversão entre os povos indígenas no Brasil. Campinas, SP: Ed. Unicamp, 1999.

. "Indivíduos celestes - cristianismo e parentesco em um grupo nativo da Amazônia". Religião e Sociedade. n. 27(1): 11-23, Rio de Janeiro, 2007.

----_--. "Conversão, predação e perspectiva". Mana. Vol.14, n.1, 2008.

2016

Praying and Preying. Oakland, USA: University of California Press,

VIVEIROS DE CASTRO, Eduardo. "Atualização e contra-efetuação do virtual na socialidade amazônica: o processo de parentesco". Ilha Revista de Antropologia. v. 2, n. 1, p. 5-46, 2000.

."O mármore e a murta: sobre a inconstância da alma selvagem". In: $A$ inconstância da alma selvagem - e outros ensaios de antropologia.2.ed. São Paulo: Cosac Naify, 2011.

WRIGHT, Robin. "O tempo de Sophie: história e cosmologia da conversão baniwa". In: WRIGHT, Robin (org.). Transformando os deuses: os múltiplos sentidos da conversão entre os povos indígenas no Brasil. Campinas, SP: Ed. Unicamp, 1999. 
." As tradições proféticas e cosmologias "cristãs" entre os Baniwa". In: WRIGHT, Robin (org.). Transformando os deuses: Igrejas evangélicas, pentecostais e neopentecostais entre os povos indígenas no Brasil. Vol. 2. Campinas, SP: Ed. Unicamp, 2004.

XAVIER, Carlos C.L. Os Koripako do Alto Içana: etnografia de um grupo indígena evangélico. Museu Nacional, Rio de Janeiro, 2013. (Tese de Doutorado). 